\title{
Personnel Decision Making of Chosen Czech Banking Subjects During the Economic Recession
}

\author{
Jiří Kraft, Iva Nedomlelová, Martin Petř́iček
}

\section{Abstract}

The article focuses on personnel decision making of important banking subjects during the ongoing economic recession with the specialization on financial crisis in 2008. Main objective of the article is to verify the implicit contract theory and to answer the question of how the selected banks solve problem of reducing labour costs during the crisis. Four important banks (Česká spořitelna, a. s., Komerční banka, a. s., GE Money Bank, a. s., Raiffeisenbank, a. s.) in years 2005 - 2010 are examined. To identify the economic crisis, is used model, which is based on the model, indicating the U. S. business cycle, which uses analytical team in Raiffeisenbank. Model used in this article is based on three variables (index of industrial production, business sales, employment rate). Employment rate is separate variable. The values of business sales are adjusted to the values of basis indices, for which the year 2005 is the basis. The development of all those three variables (index of industrial production, business sales, employment rate) is similar and it is possible to determine the period from the graphical representation, in which all variables reached their maximum and reversed their trend. To support this, a trend line was added to the graphs. The trend line was determined as a moving average for the four seasons. Based on the model, the beginning of the economic recession was indentified to the turn of 2007 and 2008. The biggest slumps can be seen during the year 2009. The investigated periods are therefore the years 2008 and 2009.

The calculations of other variables, describing the current condition of the studied subject, are adjusted to the values of basis indices in the same way as the business sales. The year 2005 is set as a basis. Data from chosen banks' annual reports were used to study their current condition. The basic monitored data are: labour costs, number of employees and earnings after tax (EAT). This article focuses attention on the personal decisions of banks, especially on the monitoring of costs of employees and their evolution over time in the context of economic recession. The essential conclusion is the confirmation of the implicit contract theory of the new Keynesian economics, which appeared at all observed subject. It is possible to see a year delay

1) The article was published under financial support of project GA ČR 402/09/0592. 
between the reduction of the employees and reduction of salary costs. This delay causes further costs. The reduction was observed in all subjects.

Keywords: | banks, recession, salary costs, net profit, new Keynesian economics

Classification JEL: E32, G21

\section{Introduction}

The banking environment is specific by its salary variedness and therefore by larges space for salary costs manipulation. The salary variedness has to be divided into two basic categories. First category is made up by employees directly dealing and generating profit for the bank - usually employees of particular branches and on lower managerial positions or employees directly in business sections. The second category consists of administrative and managerial background of the whole bank (Synek, 2002). The public usually perceive the second category with criticism and as an extremely demanding part of a company regarding the costs. However it constitutes an important part of the company as it plays an important role during crisis and their decision making affects the smooth running of the bank (Samuelson, 1985; Elsby et al., 2010).

Banks from the top positions of the Czech market and on the contrary banks with lower market share were chosen for the analysis. The „internet banks“, were omitted since their character and business orientation are different of the banks - in the way they are understood in the Czech Republic (Severin, 2010). The comparison of those bank's behaviour and decision making would be therefore not appropriate. Speaking of particular banks that were investigated - the group of big banks was represented by the companies: Česká spořitelna and Komerční banka. The group of banks with lower market share consists of the Raiffeisenbank and the GE Money Bank.

The field of banking was chosen for several reasons. The 2008 crisis has been often described as a financial crisis. Its beginning is also linked with the crisis on mortgage market in the United States (Caballero, 2008; Greenspan, Mankiw, Stein, 2010). "Academia, research and policy-makers still discuss who is responsible for the present financial turmoil. There is a general accepted agreement that the present global financial crisis is the result of complex issues." (Sipko, 2011, p. 33)

The health of banking sector of whole Europe is one of the key questions of nowadays mainly because banks represent an important pillar supporting economic activity and stand for as an intermediate of the support of an economic development. (Gorton, 2010). The issue of labor market associated with crisis is also mentioned, for example, in the articles written by Elsby or Blanchard. (Elsby et al., 2010; Blanchard et al., 2010).

\section{Model of determination the economical recession}

The first important assumption is to define a period which will be marked as a period of economic crisis. The basic model defining the crisis is based on the prediction model, compiled by team of analysts in Raiffeisenbank, under the leadership of Pavel Mertlík. The original model focuses on the United States economic cycle and it is demonstrated on graph 1 . 
Graph 1: Model of USA business cycle

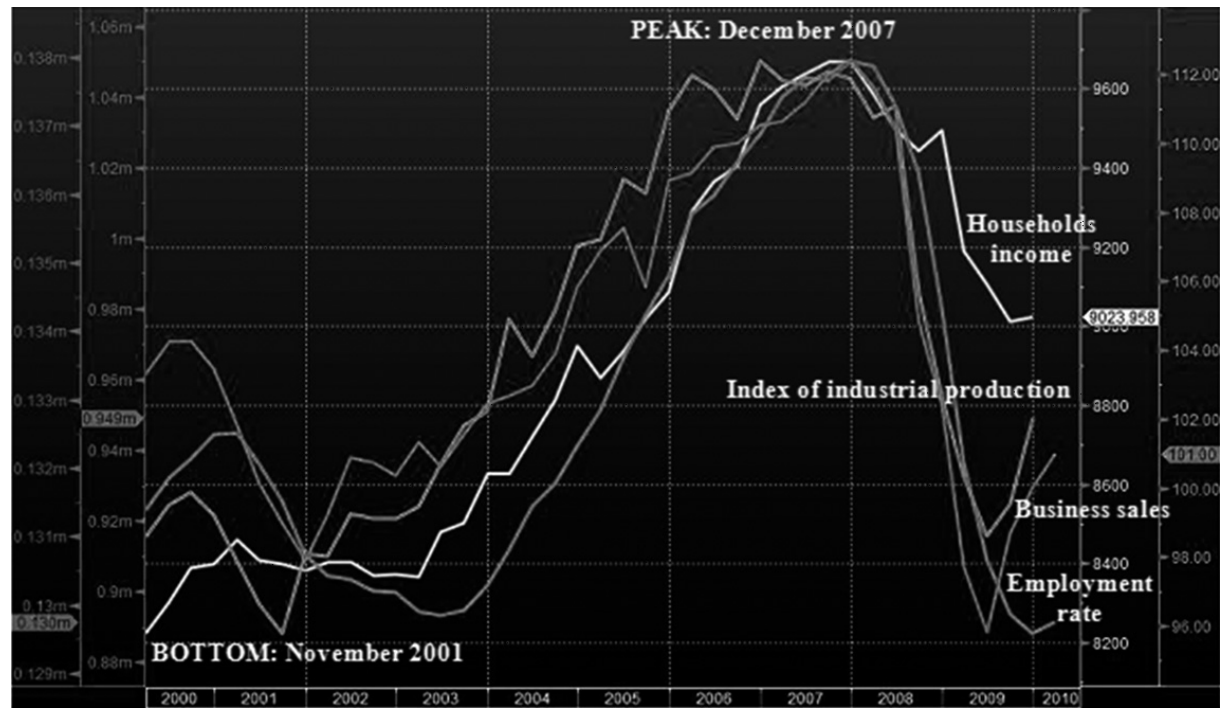

Source: http://www.atoz.cz/soubory/horeka112/michl.pdf

The prediction model was adjusted for needs of this article, to monitor the environment of the Czech Republic. The original model presumes four basic variables: Households incomes, rate of employment, index of industrial production and business sales. All these variables are illustrated in a single graph, which reflecting the economic development.

The modified model analyzes three selected variables (business sales, the index of industrial production and employment rate). Calculations and graphical representation of these variables are based on quarterly data. Conversion of business sales, provided in the methodology is implemented as follows.

$$
X_{T / 2005}=\left(X_{T} / X_{2005}\right) * 100,
$$

$X_{T / 2005}$ is conversion value (business sales) of the year $T$.

Trend line, which helps determine the current evolution of the monitored values (trade sales, industrial production index) is calculated as the moving average.

$$
M A=(X 1+X 2+\ldots+X n) / n,
$$

$M A$ is the moving average, $X 1 \ldots X n$ are the variables (index of industrial production, business sales, employment), $\mathrm{n}$ is the number of periods that determine the trend. In the article, the trend is based on four periods $(n=4)$.

When the analyzed variables (index of industrial production and business sales) are assembled to a time series, it is possible in this simple mode to monitor the economic development of the Czech economy. Both indicators are adjusted according to the used methodology (converted to values of 2005), which allows to formulate relevant conclusion. Graph 2 demonstrates that the peak can be found in the turn of the years 2007 to 2008 and we can identify 2008 as the year when the recession hit the economy. All the values declined until the second half of 2009, when the trend reversed and a revival of the economy began. 
Graph 2: Business sales and industry in Czech Republic during years 2005 - 2010

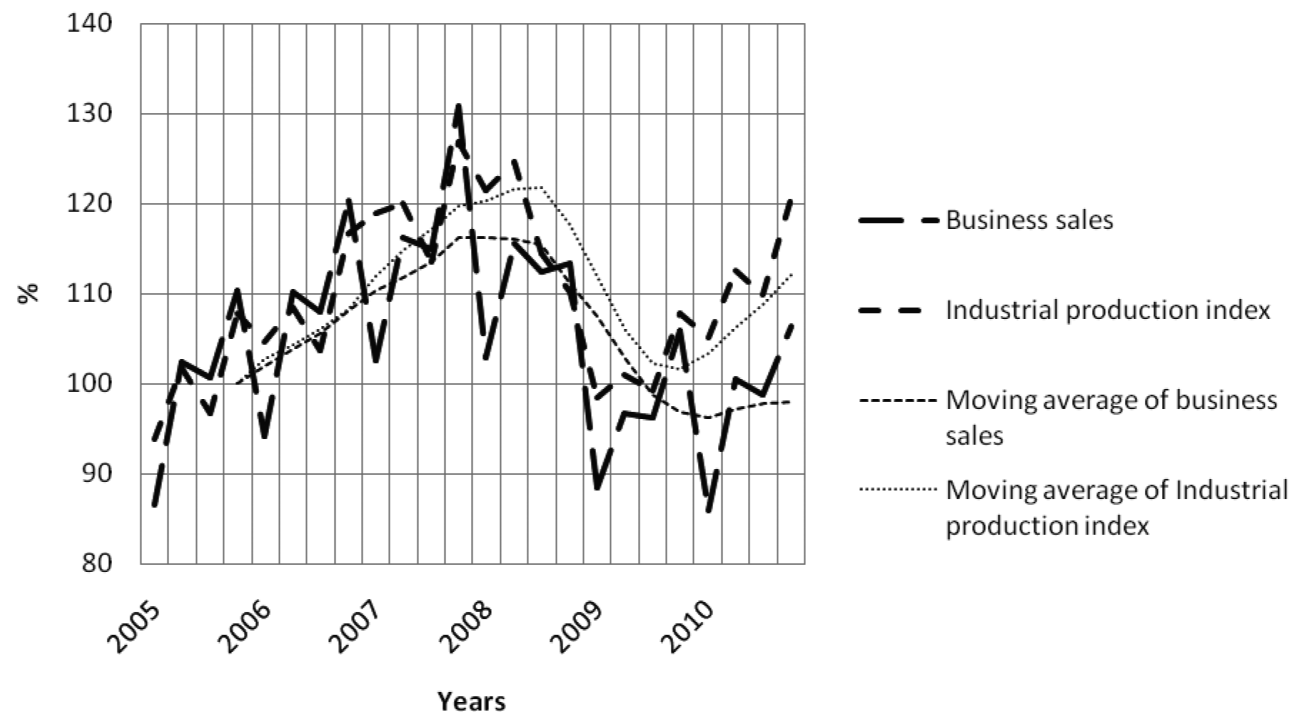

Source: http://www.czso.cz/; graphical depiction by authors

The third monitored indicator is the overall employment rate in the Czech Republic measured in \%. Time series of the employment rate is shown in graph 3. Its level in 2008 and for the majority of 2009 remained without significant changes, it even increased slightly. Only in the second half of 2009, employment started declining rapidly down to its bottom in the first quarter of 2010. The development of the employment rate is slow, reflecting the market behaviour and the economic situation with roughly 12-month delay.

Graph 3: Employment in Czech Republic in the years 2005 - 2010

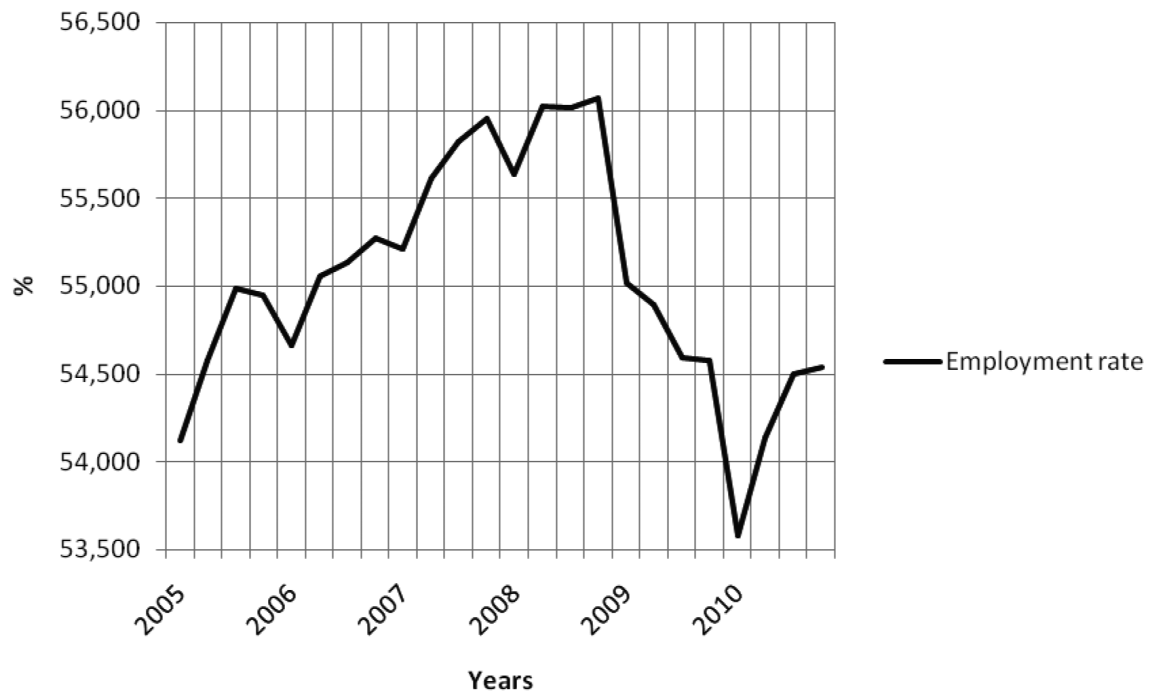

Source: http://www.czso.cz/; graphical depiction by authors 
The period of the crisis, defined by the model above, is the beginning of 2008 . The following section will try to describe the behaviour of banks and to highlight their main decision making and its consequences right in this period. At the moment when a bank's senior management decides for proper action and begin to implement it, it should be reflected in the monitored economic results of whole company.

\section{Analysis of changes in personnel decisions}

The main indicator reflecting the bank's economic situation is EAT (Synek, 2002). For comparison of individual banking subjects from personnel point of view, the value of EAT is converted to EAT per one employee, so it is the average profit per employee. An important phrase of development of this indicator is just over the period $2008-2009$. The time series is shown in graph 4.

Graph 4: EAT per employee

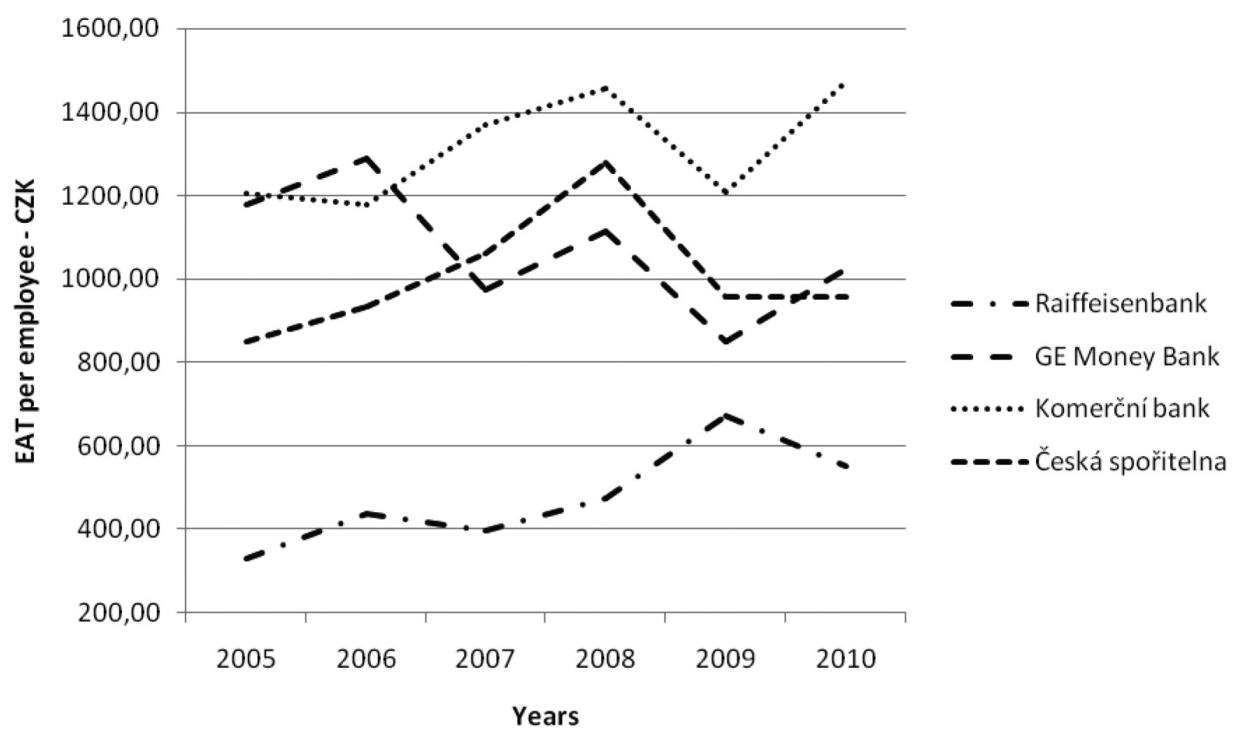

Source: Bank's annual reports; graphical depiction by authors

It can be observed, EAT value of three out of the four selected banks significantly decreased during the reporting period. Only EAT of the Raiffeisenbank rose. This can be explained by the fact, the Raiffesenbank experienced a significant business expansion into new markets, especially the market of premium banking, in this period.

Given the increasing trend is observed in a significant increase in the number of employees (see below), it can be stated the commercial success of this expansion mean also the rise of EAT per employee, but only in this single period. The following year, when EAT of all the other banks increase, Raiffeisenbank declined. The Raiffeisenbank was unable to eliminate the impact of economic recession on the EAT.

An important explanatory power has the value of unit labour costs (per one employee). The development of this variable shows how much wage cost falls to one employee. The graph 5 shows this value during the monitored years. 
Graph 5: Wage per employee

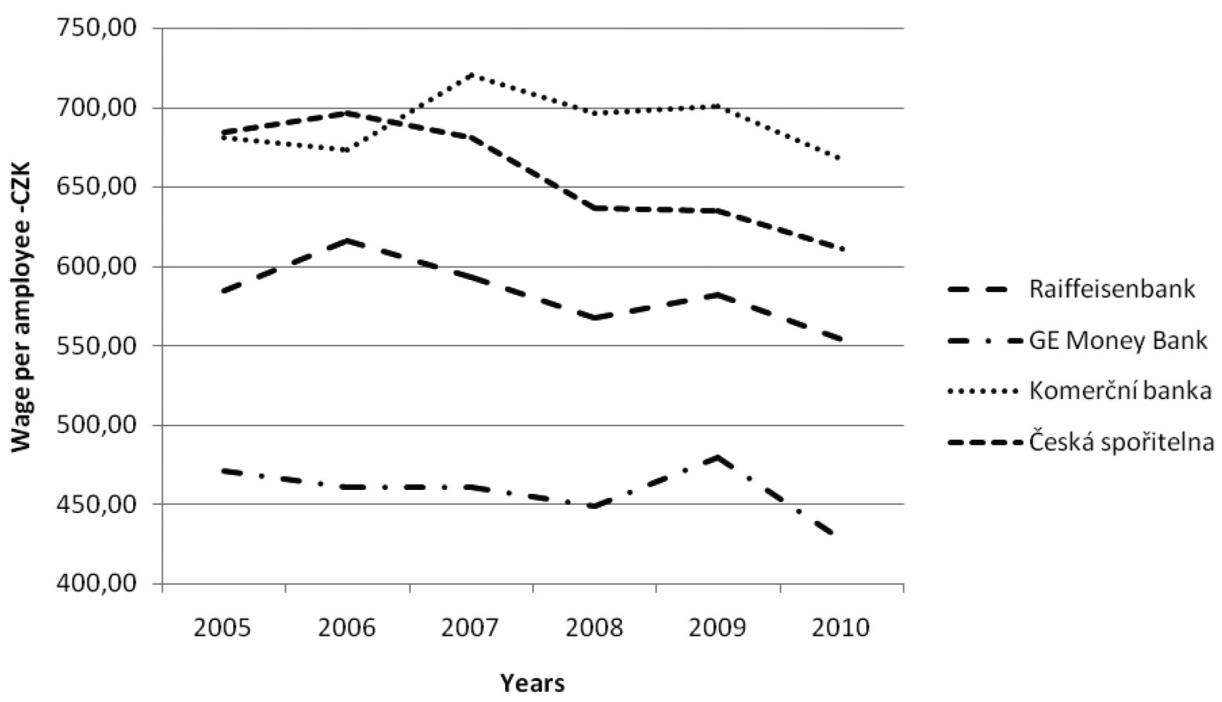

Source: Bank's annual reports; graphical depiction by authors

Graph 5 demonstrates an interesting issue. During the monitored period, therefore in the period between 2008 and 2009, unit labour costs in 3 chosen banks rose, while in the Česká spořitelna a downward trend was only slightly suspended. Why would, during the crisis, the banks act in a way that would raise their labour costs? The answer could rest in the existence of strong trade union (McConnell, Brue, 1992). Another important factor that reflects the personal decisions of banks during the crisis is the number of employees of these banks. Percentage change in the number of employees between years 2008 and 2009 is shown in the table 1.

Table 1: Changes in the number of employees

\begin{tabular}{|l|c|}
\hline \multicolumn{2}{|c|}{ Changes in the number of employees } \\
\hline Raiffeisenbank & $0,99 \%$ \\
\hline GE Money Bank & $-1,96 \%$ \\
\hline Komerční bank & $-0,29 \%$ \\
\hline Česká spořitelna & $-1,32 \%$ \\
\hline
\end{tabular}

Source: Bank's annual reports; calculations by authors

Values show only slight changes, which is why they could not significantly affect the value of unit labour costs. But the point is that during the crisis three out of four monitored banks reduced the number of their employees. The situation in the Raiffeisenbank is more specific. We can say that although this bank did not reduce the number of employees, it significantly suspended the increase of the number of its employees, before the crisis and after 2009. So, all monitored banks either slowed growth of recruiting new employees or began to limit their number. This fact was demonstrated during the crisis between 2008 and 2009. Long-term trend is shown in the following graph 6 . 
Graph 6: Number of employees

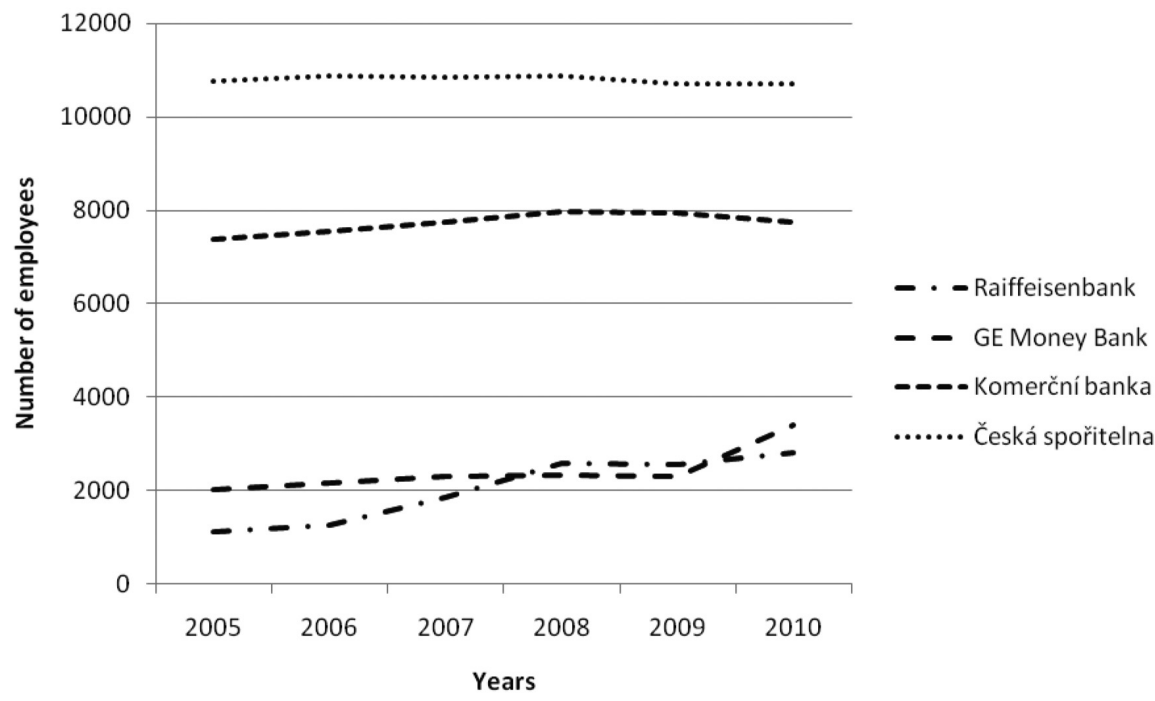

Source: Bank's annual reports; graphical depiction by authors

An interesting result from the graph 5 and graph 6 is that unit labour costs did not fall significantly in years of crisis, till 2010, and this counts for all monitored banks. Conclusion is, that only in the upcoming revival of the Czech economy, some banks increase the number of employees, but not costs per unit. Comparison of changes in unit labour costs during the crisis and in the subsequent period is shown in table 2.

Table 2: Changes in the unit labour costs

\begin{tabular}{|l|c|c|}
\hline \multicolumn{3}{|c|}{ Changes in unit labour costs } \\
\hline \multicolumn{1}{|c|}{ Bank } & $2008-2009$ & $2009-2010$ \\
\hline Raiffeisenbank & $2,61 \%$ & $-4,89 \%$ \\
\hline GE Money Bank & $8,35 \%$ & $-10,85 \%$ \\
\hline Komerční banka & $0,70 \%$ & $-4,78 \%$ \\
\hline Česká spořitelna & $-0,35 \%$ & $-3,71 \%$ \\
\hline
\end{tabular}

Source: Bank's annual reports; calculations by authors

We may conclude - based on comparison of graphs 5 and 6 that banks in the first step of reducing personnel costs decrease the number of employees. After that, in the second step, they save the labour costs as such, which means cutting down wages. This phenomenon was confirmed in all monitored banks. The question is, if this behaviour of the management is acceptable. What are the reasons for this behaviour and what are its consequences? One of the negative consequences could be that banks lose skilled and competent employees who would be willing to work even for a lower wage (Samuelson, 1985; Elsby et al., 2010). Another consequence is the persistent unnecessarily high costs of employees during the crisis. All banks were finally forced to reduce unit labour costs. Only the reduction, showed up with about a year's delay. 


\section{Comparison of reality with the implicit contract theory}

The situation described above corresponds to the new Keynesian economics, to the implicit contract theory (Bal et al., 1988). In this theory, employers are trying to give the assurance of stable wages and they respond to short-term fluctuations in demand for their products by dismissals (recruitment) of employees. Companies keep the amount of wages. "At a less aggregative level, it is standard collective bargaining procedure to predetermine money wage rates for two or three years in advance, even though wage rigidity does not promote employment in recessions." (Stiglitz, Azariadis, 1983, p.188).

This theory is closely followed by the insider-outsider theory (Leslie, 1992), which describes that the company divides its employees into those who the company wants to keep and those who the company does not need and who will be thus dismissed first (Stiglitz, Azariadis, 1983). So the wage costs react with a delay to the personnel decision-making of monitored banks. In addition to the implicit contract theory, this delay may be caused by negotiations with trade unions about the amount of wages. The main objective of trade unions is to maximize the amount of economic rent (Kraft, Bednářová, Kocourek, 2011). Graph 6 indicates this situation, where $\mathrm{S}_{\mathrm{L}}$ curve represents supply of labour and also its function of average factor cost (labour). $\mathrm{MRP}_{\mathrm{L}}$ is curve which represents marginal revenue productivity of labour and curve called MRL is marginal wage. The optimal amount of labour hired is determined by the intersection of curves $S_{L}$ and $\mathrm{MR}_{\mathrm{L}}$. If the unions want to maximize economic rent the wage will be on the highest possible point on the demand curve of labour. At this wage $\left(\mathrm{W}_{1}\right)$ company is

Graph 6: Labour market; maximize economic rent

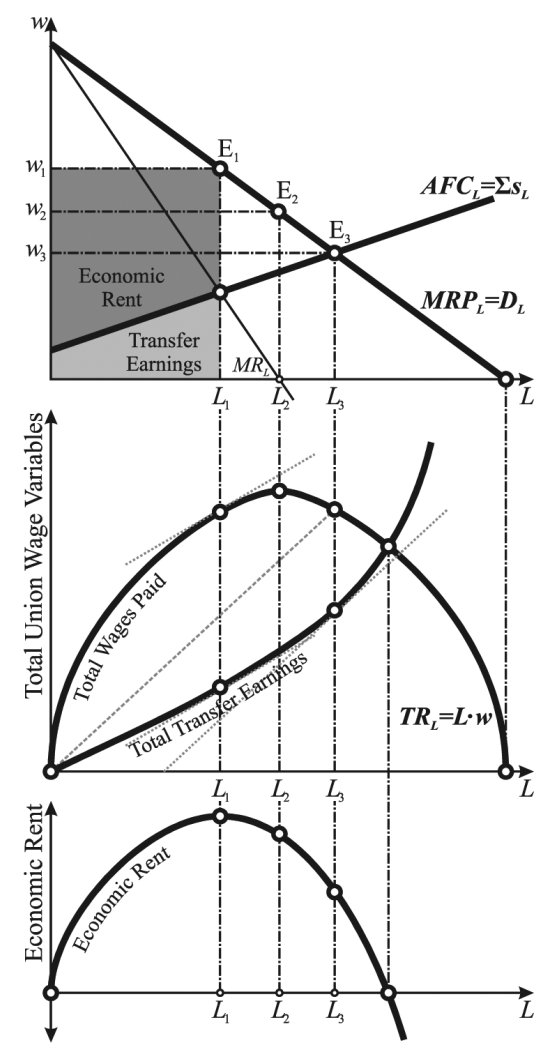
willing to employ $\mathrm{L}_{1}$ workers.

Source: Kraft, Bednářová, Kocourek, (2011, p. 153)

The aim of economic rent maximization has prevailed over the aim of maximal employment, this belonging rather to the union's aims. The maximization of economic rent has become important to such an extent, that when bank were about to decide whether to lay off the employees or to save costs by another way, they chose the laying off. In fact, this means nothing but cutting the total wage paid, lower the wage rates to the employees, which is not easy with regard to the imperfectly competitive labour market. To maximize the desired effect a global reduction in wages is necessary. Sacrifying some of the percentage of the employees is then easier for the unions. If the wages will reduced 
globally, it would affect a much higher percentage of employees and therefore a higher percentage of those, who choose, who will represent them in the unions.

\section{Conclusion}

The period of economic crisis was (based on the introduced model) proved between 2008 and 2009. To indentify the absolute decline of the performance of the Czech economy a development of two indicators (business sales and index of industrial production, whose values kept dropping considerably in the mentioned years) was used. At the same time by the beginning of 2008 the employment stopped rising and started its considerable fall during 2009. The situation in different banking subjects is similar. We can see a phenomenon, confirming the implicit contract theory. This theory of new Keynesian economics can explain an important process, where banks during the crisis at first start to fire its employees and only then try to find a way how to cut down the wage costs without reduction of the number of employees. The unit labour costs were lowered with delay, as late as in 2010. One of the main causes of this effect can rest in the negotiations with unions or other groups representing the employees. This primal aim is maximization of the salaries. Even though, the unions never achieved its goals during the crisis, the unfavourable situation forced the banks to lower the salaries a year later. Not only that this step resulted in higher additional costs for the banks, but also in a needless laying off of some employees, who could generate further profit for the bank in the future.

\section{References}

Ball, L., Mankiw, G., N., Romer, D., Akerlof, G., A., Rose, A., Yellen, J., Sims, C., A. (1988). The New Keynesian Economics and the Output-Inflation Trade-Off, Brooking Papers on Economic Activity, Vol. 1988, No. 1, pp. 1-82. [online] Available from internet <http://www.economics.harvard.edu/files/faculty/40_New_Keynesian.pdf>

Blanchard J. O., Faruqee H., Das M., Forbes J. K. (2010). The initial Impact of the Crisis on Emerging Market Countries, Brooking Papers on Economic Activity, pp. 263-323. [online] Available from internet: 〈http://www.jstor.org/stable/40930485>

Caballero, R., J., Farhi, E., Gourinchas, P. (2008). Financial Crash, Commodity Prices, and Global Imbalances, Brooking Papers on Economic Activity, Vol. 2008, pp. 1-55. [online] Available from internet: <http://www.jstor.org/stable/27720394>

Česká spořitelna - Annual Reports, [online] [Cited 2011-11-15] Available from internet: <http://www.csas.cz/banka/appmanager/portal/banka?_nfpb=true\&_pageLabel=downloads_subportal03\&dtree=en\&selnod=37>

Czech statistical office, 〈http://www.czso.cz>

Elsby W. L. M., Hobijn B., Șahin A., Katz F. L. (2010). The Labour Market in the Great Recession [with Comments and Discussion], Brooking Papers on Economic Activity, pp. 1-69. [online] Available from internet: < http://www.jstor.org/stable/40930481>

GE Money Bank - Annual Reports, [online] [Cited 2011-11-15] Available from internet <http://www.gemoney.cz/ge/en/1/about-us/annual-reports>

Gorton G., Metrick A., Shleifer A., Tarullo D. K. (2010). Regulating the Shadow Banking System [with Comments and Discussion], Brooking Papers on Economic Activity, pp. 261-312. [online] Available from internet: < http://www.jstor.org/stable/41012848> 
Greenspan A., Mankiw N. G., Stein C. J. (2010). The Crisis, Brooking Papers on Economic Activity, pp. 201-261. [online] Available from internet:

<http://www.jstor.org/stable/40930484>

Holman, R. (2005). Dějiny ekonomického myšlení [The History of Economic Thought], $3^{\text {rd }}$ edition. Praha C. H. Beck. 539 p. ISBN 80-7179-380-9.

Komerční banka - Annual Reports, [online] [Cited 2011-11-15] Available from internet: <http://www.kb.cz/en/about-the-bank/about-us/kb-publications.shtml>

Kraft, J., Bednářová, P., Kocourek, A. (2011). Mikroekonomie II. $1^{\text {st }}$ edition. Liberec Technická univerzita v Liberci. 192 p. ISBN 978-80-7372-770-3.

Leslie, D. (1992). Insider-Outsider Theory and the Case for Implicit Contracts, The Economic Journal, Vol. 102, No. 410, pp. 37-48. [online] Available from internet: <http://www.jstor.org/stable/2234850>

McConnel, R. C., Brue L. S. (1992). Contemporary Labour Economics, $3^{\text {rd }}$ edition. McGraw-Hill 660 p. ISBN 0-07-045555-4.

Michl, A. (2010). Ekonomika v nové realitě [Economy in a new reality], [online presentation] [Cited 2011-11-22] Available from internet:

<http://data.eventworld.cz/file/etime2010/prezentace/03_MICHL-etime2010.pdf>

Raiffeisenbank - Annual Reports, [online] [Cited 2011-11-15] Available from internet: <http://www.rb.cz/en/information-service/bank-profile/annual-reports/>

Samuelson, L. (1985). Implicit Contracts with Heterogeneous Labour, Journal of Labour Economics, Vol. 3, No. 1, pp. 70-90. [online] Available from internet <http://www.jstor.org/stable/2535050>

Severin, M. (2010). Sbohem bankovním pobočkám? [Goodbye bank branches?], Strategie, p. 40, [online] Available from internet: <http://www.pwc.com/cz/cs/clanky-2010/sbohem-bankovnim-pobockam.jhtml>

Sipko J. (2011). Derivates and the real economy, Creative and Knowledge Society, Vol. 1, August 2011, pp. 33-43

Stiglitz, J., Azariadis, C. (1983). Implicit Contracts and Fixed Price Equilibria, New Keynesian Economics, The MIT Press. Vol. 2, pp. 187-209. ISBN 0-262-63134-2.

Synek, M. (2002). Podniková ekonomika [Business Administration], $3^{\text {rd }}$ edition. Praha C. H. Beck. 479 p. ISBN 80-7179-736-7.

prof. Ing. Jiří Kraft, CSc.

Technical University of Liberec

Faculty of Economics

Address: Studentská 2

46117 Liberec

e-mail: jiri.kraft@tul.cz

phone number: +420 485352377
Ing. Iva Nedomlelová, Ph. D.

Technical University of Liberec

Faculty of Economics

Address: Studentská 2

46117 Liberec

e-mail: iva.nedomlelova@tul.cz

phone number: +420 485352495

\section{Ing. Martin Petříček}

Technical University of Liberec

Faculty of Economics

Address: Studentská 2

46117 Liberec

e-mail: martin.petricek1@tul.cz

phone number: +420 485352495 